\title{
The impact of traditional use on vultures in South Africa
}

\section{Steven McKean ${ }^{1 *}$, Myles Mander ${ }^{2}$, Nicci Diederichs ${ }^{2}$, Lungile Ntuli ${ }^{1}$, Khulile Mavundla ${ }^{2}$, Vivienne Williams ${ }^{3}$ and James Wakelin ${ }^{4}$}

\author{
${ }^{1}$ Ezemvelo KZN Wildlife, P O Box 13053, Cascades, 3202, South Africa. \\ ${ }^{2}$ Futureworks! PO Box 2221 Everton 3625, South Africa. \\ ${ }^{3}$ School of Animal, Plant and Environmental Sciences, University of the Witwatersrand, \\ Johannesburg, South Africa. \\ ${ }^{4}$ Deceased. \\ *Corresponding author: Steve@KZNWildlife.com
}

\section{Summary}

Use of vultures is an important component of traditional medicine, particularly in South Africa and there is evidence to suggest that traditional use is at least partly responsible for the rapid decline of vulture populations in this country. Until very recently, little information on the extent of the trade in animal parts, particularly vultures, for traditional medicine was available. The secretive and illegal nature of vulture use makes it extremely difficult to obtain reliable data on amounts and turnovers of species traded, which is essential to assess potential impacts on species populations.

Research confirms that vultures are used in the traditional medicine industry for a range of purposes, but are believed to be most effective for providing clairvoyant powers, foresight and increased intelligence. The main drivers of demand for these uses are betting and gambling, for improved business success, and intelligence in school children. Vulture is also prescribed by traditional healers for various ailments, including headaches.

It is estimated that 160 vultures are sold per annum in eastern South Africa, with some 59,000 consumption events of vulture pieces. The total annual value of sales of vultures to end consumers in eastern South Africa (excluding the costs of vultures as input costs) is estimated at R1,2 million (\$US 120k). Various species of vulture are used for traditional medicine; there is no distinct species preference. Vultures traded in the eastern South African markets are harvested by vulture hunters from a range of formally protected and unprotected natural areas in KwaZulu-Natal, Eastern Cape, Lesotho and southern Mozambique. They are killed using shotguns, poisons or traps. Poisoning is the most destructive and widely used method of harvesting as large numbers of vultures are usually killed in one poisoning event. An estimated 1,250 vulture traders, hunters and traditional healers in eastern South Africa are involved in the vulture trade.

With small vulture populations and poor breeding success, the current trade in vultures is not sustainable at the present harvest levels. The implication for people using or trading in vultures is that the benefits currently enjoyed will not be available in 15 to 30 years time. 


\section{Introduction}

There is a widely held belief in many African cultures that health, disease, success or misfortune are not chance events but the result of the active influence of individuals or ancestral spirits (Berglund 1976). For this reason, traditional medicine is held in high esteem in such cultures and is regularly used by a large proportion of the population. Traditional medicines represent herbal, animal and mineral material used for physiological as well as symbolic/psychological purposes (Cunningham 1991). Approximately $80 \%$ of the population in South Africa uses traditional medicine in one form or another because pharmaceutical drugs are too expensive or traditional methods are considered more appropriate (Cunningham 1991, Mander 1998).

The rapidly expanding commercial trade in plants and animals for traditional use is stimulated by rapid urbanisation and high levels of unemployment (Cunningham 1991). The pressure on wild populations of indigenous plants and animals for traditional medicines is probably higher than at any time in the past because many people with no alternative forms of income are turning to the harvest and sale of plants and animals to earn a living and meet rising urban demand (Cunningham 1991). Population increases, declining economy, rising unemployment and increasing uncertainty about the future are all indicators that demand for traditional medicines will continue to increase in the future (Cunningham 1991). The value of the trade in indigenous plant species for traditional medicine in KwaZulu-Natal was estimated at R65 million per annum with 4500 tonnes of plant material being sold annually (Mander 1998). Despite the persistence of customary (cultural practice) controls on the use of many species, the commercial trade and consequent economic benefits has eroded many of these controls to the detriment of the species involved and the systems in which they occur.

Little information is available on the extent of the trade in animal parts for traditional medicine. The trade in animal parts is secretive and mostly illegal in South Africa. This makes it extremely difficult to obtain reliable information on amounts and turnovers of species traded, which is essential to assess potential impact on species populations. Also, the controls over animal medicines relate to the politics of control over supernatural power from animals with powerful symbolism (Cunningham 
1991). Approximately 150 animal species are traded for traditional medicine in KwaZulu-Natal ( $\mathrm{M}^{\mathrm{c}}$ Kean 1995, Whiting et al. 2011).

Vultures are widely used throughout Africa (Williams et al. 2013) and are believed to be important for traditional medicine. There is evidence to suggest that traditional use is at least partly responsible for the rapid decline in vulture populations in South Africa. For example, there is irrefutable evidence that vultures are being killed and traded through the traditional medicine markets (Cunningham 1991, Mander et al. 2007). There are repeated media reports that the "Lotto" is contributing to population declines through stimulating demand for vultures, which are traditionally believed to have clairvoyant powers. All vulture species appear to be used, particularly as capture methods such as poisoning do not discriminate between species and all vulture species are in high demand (Ngwenya 2001).

Yet the belief system behind vulture use, the numbers of vultures killed for use, demand for vultures and the value of the trade in vulture parts for traditional medicine remains poorly understood. Is traditional medicine contributing to the documented decline in vulture populations? If so, to what extent? What main factors are driving the demand for vultures? What is the extent and value of the trade in vultures for traditional medicine? Are there effective and practical interventions that can be applied to conserve vultures while also conserving traditional belief systems?

Vultures are known to be traded in the markets for the reasons described above and vulture populations are showing decline. A short study was done of three large informal urban markets which could serve as an indicator of trade activities and volumes for South Africa.

\section{Purpose of the Study}

The overall goal of the study was to develop an understanding of the trade in vultures for traditional medicine / cultural use in South Africa. This information could then be used to inform strategy development for conservation of vulture populations threatened by high levels of use, as well as increasing general awareness of the importance of vultures as a cultural resource and as a provider of "ecosystem services" such as removal of carrion, to society. 
In this paper, we

- Assess the species and numbers of vultures used, parts used, supply sources, hunting methods, values and turnover.

- Assess ecological sustainability of vulture use levels.

- Assess the trade chain, vulture trader and user profiles.

- $\quad$ Investigate the traditional belief systems which are reported to support vulture use.

- Recommend interventions to mitigate current and future impacts of traditional use of vultures on species and populations.

\section{Methods}

The trade survey process consisted of three phases. Details of the survey process are described in Mander et al. (2007).

Phase One involved preparatory investigative work, including a literature survey, the identification of a method and approach for how and where the survey work was to be undertaken. This included identification of the markets to be surveyed, the development of a survey questionnaire and a survey programme (i.e. market monitoring frequency). As traditional medicine markets tend to be secretive and suspicious of research/survey work, phase one also involved canvassing market roleplayers in respect of their cooperation/participation in the survey.

Phase Two involved undertaking the trade survey. The survey focused on three markets where vultures are known to be traded, and which were considered to be representative of vulture wholesale and retail trade in KwaZulu-Natal and Gauteng (Fig 1).

- Faraday Market, Johannesburg

- Durban Herb Market, Durban

- Mona Market, Nongoma

The researchers already had a working relationship with the traders and Traditional Healers in two of the three markets surveyed: Faraday and Durban Herb Market. However the researchers did not have a relationship with traders / Traditional Healers at Mona Market. 


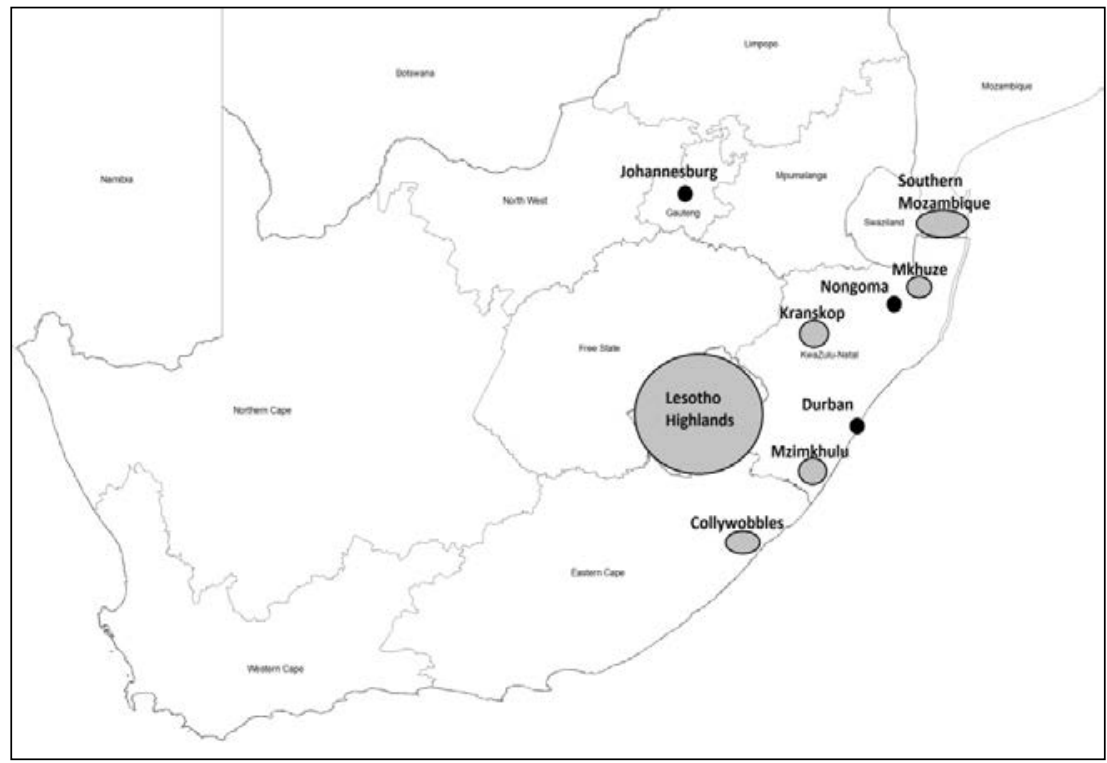

Figure 1: Map of South Africa showing locations of informal traditional medicine markets surveyed as well as source areas for vulture trade.

The survey included:

- Weekly monitoring of the Durban Herb Market,

- Monthly surveys of the Durban herb and Mona Markets, including interviews with vulture traders and Traditional Healers using a questionnaire developed during Phase 1. This questionnaire investigated aspects of the trade reported in the Results section.

- A once-off survey of the Faraday Market in Johannesburg,
- Once-off interviews with prominent Traditional Healers, vulture hunters and other knowledgeable people in the vulture trade.

The monthly and weekly monitoring of the markets and questionnaire interviews were conducted by the authors.

The weekly monitoring was conducted for a six-week period. This was intended to run for 3 months in the Durban Herb Market, however 
after 1.5 months institutional conflict within the market precluded the possibility of any further survey work taking place. The information gathered was therefore not for the desired 3-month period.

The monthly surveys were conducted for a 3-month period.

Phase Three involved the evaluation and analysis of the survey results. A workshop was held with the authors to achieve this. The results of the survey were presented and discussed at this workshop, followed by a collective identification of key issues and possible interventions to address these. Data on species and volumes traded were compared to known population size and breeding success rate data to assess ecological sustainability of estimated vulture trade levels.

\section{Results}

Who uses vultures and why? The consumers of vultures are from both genders. All age groups make use of vulture products. There is a predominance of low income groups using vulture products. The traders report that only $30 \%$ of their trade is to end consumers, while the remaining $70 \%$ is either resold to other traders or it is used by diviners on behalf of their patients. Consumers use vultures for a wide range of purposes. For many of these uses there may be alternatives that they could use, with the exception of foretelling, for luck and for increasing the intelligence of schoolchildren. The majority of buyers request the vulture products directly, with a small percentage of the traders recommending its use. The implication of this is that demand for vultures as a medical treatment / for luck or for intelligence / clairvoyance is already entrenched in the consumers. This drives a significant proportion of the demand for vultures.

Traditional Healers also drive demand for vultures by either prescribing the use of vultures or using vultures themselves to assist in making predictions for their clients. While some prescribed uses of vulture are for the treatment of medical ailments, such as headaches, Traditional Healers believe vulture is most effective for clairvoyant purposes (foretelling, often for informing gambling or betting). Importantly, Traditional Healers indicate that there are no comparable alternatives for this use. This implies that for clairvoyance use, vultures are the only product that is considered "effective", and consequently 
stopping the use of vultures for this purpose will be difficult. This seriously restricts the management options available for conservation agencies aiming to protect vulture populations from over-harvesting for the Traditional Medicine industry.

\section{Supply sources and hunting} methods: Results show that vultures are harvested for traditional use from a range of areas (Figure 1), including:

- KwaZulu-Natal (KZN) Wildlife protected areas such as uMhkuze Game Reserve and the adjoining communal areas,

- Kranskop in the Thukela valley, KZN,

- Mzimkhulu in southern KZN,

- Flagstaff and Collywobbles in the Eastern Cape where large vulture colonies exist outside protected areas,

- The Lesotho highlands, and

- Southern Mozambique.

The Kruger National Park in northeast South Africa contains large vulture populations and it could be expected that traditional medicine gatherers would target this area and its surroundings for vultures. However, discussions with Traditional Healers in the Bushbuckridge area near Kruger National Park and with South African National Parks staff indicated that they were unaware of any recent poaching or trading activity of vultures from the Park or surrounding areas (Mander et al. 2007).

Vultures are harvested by a number of methods (Figure 2). Poisoning, particularly the use of aldicarb, is the most destructive method of harvesting, as large numbers of vultures are usually killed in one poisoning event. For example, 51 vultures were poisoned in January 2007 at one carcass outside uMkhuze Game Reserve in eastern KZN (KZN Wildlife internal records). Brake fluid and insecticide were also reported to be used to poison carcasses from which vultures feed to kill vultures. 


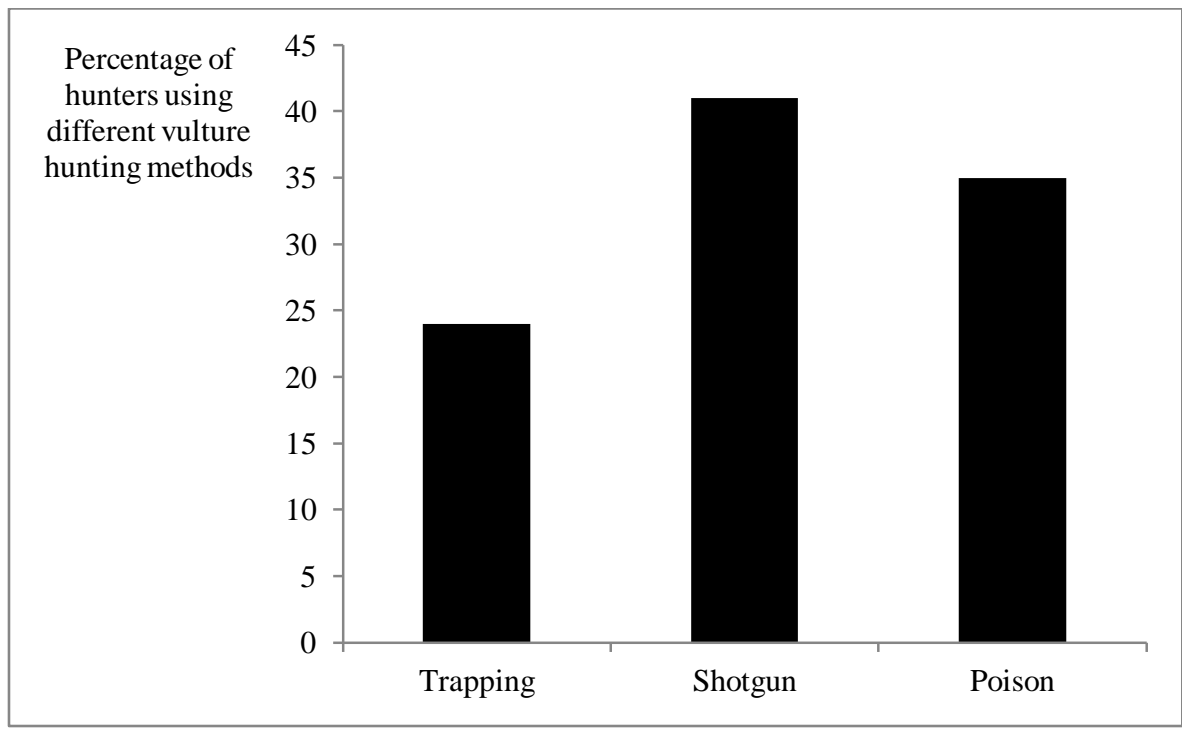

Figure 2: Graph showing percentages of hunters using different methods to kill vultures.

Trade chain: The trade in vultures follows a distinctive path or chain, with various market segments along the way. The typical trade chain starts with vulture hunters from the rural areas adjacent to protected areas in Zululand or adjacent vulture colonies in Pondoland or Southern Mozambique. There is a direct relationship between the three markets surveyed and each other. The vultures are transported either directly into the Durban market, or first to rural markets, such as Mona, where they are wholesaled and then transported to Durban. Mona Market is a monthly market in Hlabisa (in eastern KZN) which functions largely as a wholesale market to Durban and other smaller towns in KZN. In Durban the vultures are either wholesaled again to Traditional Healers and / or retailed to consumers. In Durban the vultures can also be re-sold into the Johannesburg markets, like Faraday and Mai Mai (Johannesburg). Many of the traders in Faraday Market in Johannesburg are Zulu and they source most of their material from associates in Durban. There are however alternative trade routes with material traded directly into Durban and Faraday from other areas, such as the eastern Cape, Mpumalanga, 
Southern Mozambique and Lesotho (see Figure 1).

Use of different species: Different species of vultures are traded, but many Traditional Healers and vulture traders indicated no preference for trading any particular species. Cape Vultures Gyps coprotheres and White-backed Vultures Gyps africanus were reported as being "preferred" for trade through the survey, but this is most likely related to the greater availability of these species over other vulture species, an inability to differentiate between the two (as demonstrated during the survey during discussions with traders), and the fact that these species are known - rather than a real preference for these species over others.

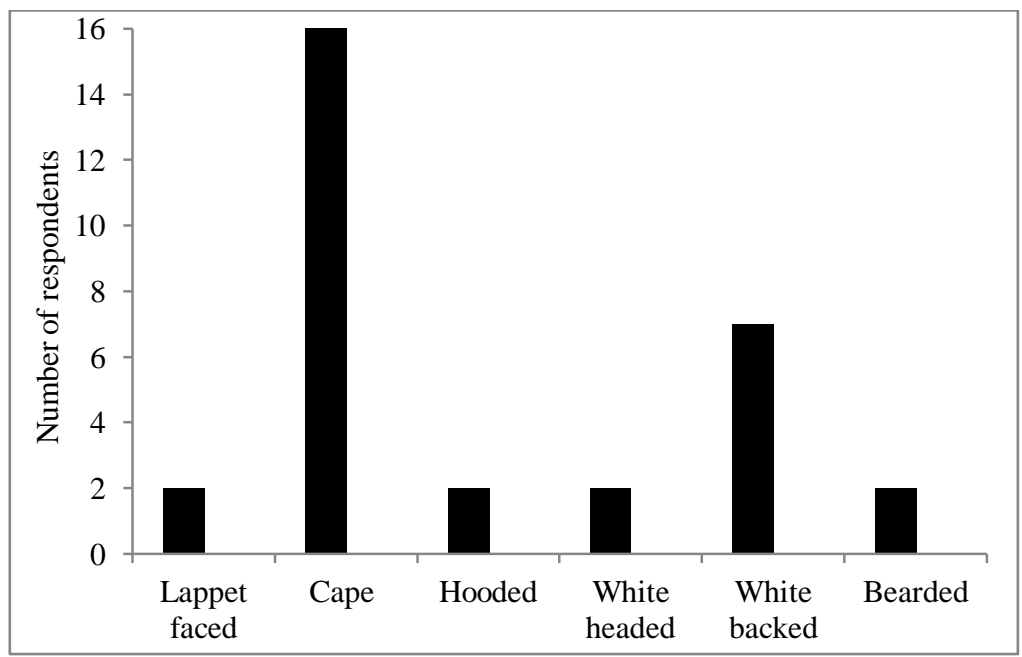

Figure 3: Numbers of survey respondents and preferred vulture species.

Tables 1 and 2 give a broad estimate of the numbers of vultures traded during the survey period and a translation of this into the number of vultures traded per annum. This information is based on observed data with some assumptions (see Table 3). 
Table 1: Estimates from a series of market surveys in southern Africa of the number of vultures traded per market

\begin{tabular}{|l|l|l|l|l|}
\hline Market location & Mozambique & Mona & Durban & Faraday \\
\hline $\begin{array}{l}\text { Number of vultures observed or } \\
\text { reported traded - based on } \\
\text { observations in the market }\end{array}$ & 5 & 16 & 11 & 10 \\
\hline Period of trade surveyed - days & 92 & 92 & 40 & 92 \\
\hline $\begin{array}{l}\text { Estimated vultures traded per } \\
\text { day }\end{array}$ & 0.05 & 0.17 & 0.28 & 0.11 \\
\hline $\begin{array}{l}\text { Vultures traded per year - } \\
\text { assuming survey period is } \\
\text { representative of annual trends }\end{array}$ & $\mathbf{2 0}$ & $\mathbf{6 3}$ & $\mathbf{1 0 0}$ & $\mathbf{4 0}$ \\
\hline
\end{tabular}

As considerable inter-market trade takes place it is not possible to sum the numbers from Table 1 to get the total trade volume. Table 2 estimates the total number of vultures sold across the markets that were surveyed.

Table 2: Combined vulture trade estimates for markets in Mozambique, Mona, Durban and Faraday

\begin{tabular}{|l|l|l|}
\hline Vulture trade & Number traded & Source of Information \\
\hline $\begin{array}{l}\text { Rural sources - } \\
\text { Mona and } \\
\text { Mozambique }\end{array}$ & 83 & $\begin{array}{l}\text { 63 Vultures from Mona market } \\
\text { 20 Vultures from Mozambique }\end{array}$ \\
\hline $\begin{array}{l}\text { Urban wholesale } \\
\text { and retail }\end{array}$ & 140 & Durban + Faraday sales \\
\hline $\begin{array}{l}\text { Unaccounted for } \\
\text { vultures (rural } \\
\text { sources not } \\
\text { identified) }\end{array}$ & 37 & $\begin{array}{l}\text { Durban : 100 - 83 = 17 (these are then } \\
\text { likely to be Cape Griffons not via Mona } \\
\text { market) } \\
\text { Faraday : } 40-20 \text { (Vultures resold from } \\
\text { Durban) = 20 (these are likely to be } \\
\text { vultures from anywhere in RSA) }\end{array}$ \\
\hline $\begin{array}{l}\text { Total number of } \\
\text { vultures sold using } \\
\text { combined } \\
\text { estimates }\end{array}$ & $\mathbf{1 2 0}$ & $\begin{array}{l}\text { Total retail number (140) less the vultures } \\
\text { sold on from Durban to Faraday (20) }\end{array}$ \\
\hline
\end{tabular}


Based on the data from Tables 1 and 2 , a number of scenarios for the total number of vultures traded per annum in South Africa have been developed. It is estimated that between 106 to
240 vultures could be traded per annum, with 160 vultures traded per year being the most likely scenario (Table 3). An estimate of the value of the trade is computed in the next section.

Table 3: Scenarios for total number of vultures traded per annum in South Africa

\begin{tabular}{|c|c|c|}
\hline Scenarios & $\begin{array}{l}\text { Number } \\
\text { Traded }\end{array}$ & Details \\
\hline $\begin{array}{l}\text { Mona, Durban and } \\
\text { Faraday - } \\
\text { Assume they comprise } \\
\text { the total trade in RSA } \\
\text { per annum }\end{array}$ & 120 & $\begin{array}{l}\text { This excludes all traditional medicine shops } \\
\text { in large and small towns - probably between } \\
200 \text { to } 300 \text { shops in eastern RSA, of which up } \\
\text { to } 30 \% \text { may trade bird products. } \\
\text { This excludes rural trade in both pension day } \\
\text { markets and in Traditional Healers' practices } \\
\text { in eastern South Africa under traditional } \\
\text { authority. }\end{array}$ \\
\hline $\begin{array}{l}\text { Mona, Durban and } \\
\text { Faraday - } \\
\text { Assume they comprise } \\
50 \% \text { of the total trade in } \\
\text { RSA per annum }\end{array}$ & 240 & $\begin{array}{l}\text { This estimate seems plausible given that } \\
\text { Durban and Mona are regional trade hubs, but } \\
\text { that there are still several hundred outlets } \\
\text { which could potentially sell vultures. Reports } \\
\text { from rural areas indicate a scarcity and } \\
\text { infrequent use. }\end{array}$ \\
\hline $\begin{array}{l}\text { Mona, Durban and } \\
\text { Faraday } \\
\text { Assume they comprise } \\
66.6 \% \text { of the total trade } \\
\text { in RSA per annum }\end{array}$ & 160 & $\begin{array}{l}\text { Here we assume that the major markets } \\
\text { dominate the trade, but that there is still some } \\
\text { trade in other centres. This is probably the } \\
\text { most likely scenario. }\end{array}$ \\
\hline $\begin{array}{l}\text { Mona, Durban and } \\
\text { Faraday } \\
\text { Assume } 120 \text { is a } 33 \% \\
\text { over-estimate, and } \\
\text { comprises } 66.6 \% \text { of the } \\
\text { total trade }\end{array}$ & 106 & $\begin{array}{l}\text { This is a very conservative estimate that } \\
\text { assumes the } 92 \text { day survey period showed an } \\
\text { abnormally high trade in vultures. }\end{array}$ \\
\hline Likely range & \multicolumn{2}{|c|}{106 to 240 vultures traded per annum } \\
\hline Mean (of all scenarios) & \multicolumn{2}{|c|}{$\begin{array}{l}157 \text { vultures traded per annum (mirrors most likely } \\
\text { scenario - used hereafter as the annual trade estimate) }\end{array}$} \\
\hline
\end{tabular}


Parts used, values and turnover: brains are not available or the The mean annual trade value of consumer indicates that these are too vultures at wholesale prices at the markets surveyed was obtained during the survey process. These values are shown in Table 4 . Traditional Healers indicated a preference for using / prescribing certain parts of the vultures, mainly the head and brains. While this is the case, they will use other parts for treatment (probably when the head / expensive). There is a clear link between the preference for different parts of vultures and prices paid by consumers for these. The head and neck, which are most preferred as a treatment or for use by Traditional Healers, carry a higher price per unit (i.e. per single treatment) than any other part of the body.

Table 4: Mean annual value of the vulture trade at wholesale prices in South Africa

\begin{tabular}{|l|l|}
\hline Market & $\begin{array}{l}\text { Value of trade (average } \\
\text { cost per vulture) }\end{array}$ \\
\hline Faraday & R 800 \\
\hline Durban & R 250 \\
\hline Mona & R 300 \\
\hline & \multicolumn{2}{|l|}{} \\
\hline Mean & R 450 \\
\hline \% of trade as White-backed & $77 \%$ \\
\hline \% of trade as Cape Griffon & $22 \%$ \\
\hline Price per kg - by weighted average mass for vultures & R73 \\
\hline Mean value of the trade at wholesale prices & R 54,095.38 (\$US 1 R 10) \\
\hline
\end{tabular}

The wholesale value is the possible income which the hunters and traders could make when selling the whole vulture to other traders or Traditional Healers. However, these products then get resold. The estimated retail value of the vulture products sold over the counter or by traditional healers is calculated in Table 5 below. The total value of vulture sales could be at least R1.185 million per annum. However, this is likely to be an underestimate, as the healers are likely to charge more than R20 when 
using vultures parts for clairvoyance. patient. The figure of R1.185 million It is not possible to separate the value is therefore a conservative but of the healer's service and the value realistic estimate of value. of the vulture parts used in assisting a

Table 5: Assumptions and calculations of average annual retail trade value

\begin{tabular}{|l|l|l|}
\hline White-backed vulture & $\begin{array}{l}\text { Weight / } \\
\text { Value }\end{array}$ & \\
\hline Average mass & 5.5 & $\mathrm{~kg}$ \\
\hline $\begin{array}{l}\text { Likely number traded: 63 Mona vultures and 20 Mozambique } \\
\text { vultures likely to be White-backed vultures. Of the 20 additional } \\
\text { vultures in Faraday (not from Durban), 10 could be White- } \\
\text { backed. }\end{array}$ & 93 & \\
\hline Total mass traded per annum & $\mathbf{5 1 1 . 5}$ & $\mathbf{k g}$ \\
\hline Cape Vulture & $\begin{array}{l}\text { Weight / } \\
\text { Value }\end{array}$ & \\
\hline Average mass & 8.5 & $\mathrm{~kg}$ \\
\hline $\begin{array}{l}\text { Likely number traded: 17 remaining Durban vultures from } \\
\text { Pondoland and are therefore Cape Vultures. Of the 20 additional } \\
\text { Vultures in Faraday, 10 could be Cape Vultures. }\end{array}$ & 27 & \\
\hline Total mass traded per annum & $\mathbf{2 2 9 . 5}$ & $\mathbf{k g}$ \\
\hline Total mass of Durban vulture sales per annum & 741 & $\mathrm{~kg}$ \\
\hline Tradable \% remaining when carcass eviscerated & $80 \%$ & \\
\hline Total mass sold for all species & $\mathbf{5 9 2 . 8}$ & $\mathbf{k g}$ \\
\hline & $\mathbf{R}$ & \\
\hline \% sold to traders, Traditional Healers, diviners (based on survey) & $70 \%$ & \\
\hline Mass sold to traders, Traditional Healers, diviners & 415 & $\mathrm{~kg}$ \\
\hline Individual healer purchases - mass per sale & 400 & $\mathrm{~g}$ \\
\hline Likely number of sales & 1037 & \\
\hline Average price & $\mathbf{R} 250$ & \\
\hline Price per kg & $\mathbf{R} 625$ & \\
\hline Total annual expenditure by Traditional Healers & \\
\hline
\end{tabular}


Table 5 - continued.

\begin{tabular}{|c|c|c|}
\hline & Weight/value & \\
\hline $\begin{array}{l}\text { \% sold over the counter to customers (based on survey } \\
\text { findings) }\end{array}$ & $30 \%$ & \\
\hline Mass sold to over-the-counter consumers & 178 & $\mathrm{~kg}$ \\
\hline $\begin{array}{l}\text { Individual over-the-counter consumer purchases - mass per } \\
\text { sale }\end{array}$ & 10 & g \\
\hline Likely number of sales & 17784 & \\
\hline Average price & R 20 & \\
\hline Price per kg & R 2,000 & \\
\hline Total expenditure by over-the-counter consumers & R 355,680 & \\
\hline $\begin{array}{l}\text { Sales by Traditional Healers to consumers : Traditional } \\
\text { Healers volumes resold to patients }\end{array}$ & 414.96 & $\mathrm{~kg}$ \\
\hline Mass of individual sales & 10 & g \\
\hline Price per sale & R 20 & \\
\hline Likely number of sales & 41,496 & \\
\hline Costs to patients on an annual basis & R 829,920 & \\
\hline $\begin{array}{l}\text { Total Annual Value of sales to end consumers } \\
\text { (excluding costs of vultures as inputs) }\end{array}$ & R 1,185,600 & \\
\hline
\end{tabular}

\section{Discussion}

The use of vultures for clairvoyance combined with the perception of many Traditional Healers (61\%) that there are no feasible alternative products, means that there is likely to be an ongoing and undiminishing demand for vultures for the Traditional Medicine industry. While the numbers of vultures traded (approximately 160 per annum in eastern South Africa) and their economic value are relatively small (approximately R1.2 million or \$US 120,000 per year), they still constitute an important trade item for the traders / Traditional Healers. There are some 15 traders in Durban and 
Johannesburg who trade vultures probably supplied by about six hunters. These 21 individuals may be earning some R2,571 per year, or R214 per month (assuming they all earn equal amounts and using wholesale prices).

It is estimated that there are some 59,000 consumption events of vulture per annum (assuming one use per consumer per annum), and this could mean that there are some 4,916 sales per month (at $10 \mathrm{~g}$ per sale). Assuming that Traditional Healers prescribe vulture use once a week, then it is possible that 1,230 Traditional Healers (which is not dissimilar to the 1,037 possible sales based on wholesale purchases of $400 \mathrm{~g}$ ) could benefit from the trade, to the value of R963 each per annum, or R80 per month. For the average healer this could represent between $5 \%$ and $10 \%$ of their incomes. It is unlikely that any one person in the trade relies to any great degree on the incomes generated by vultures. Most hunters and traders trade a wide range of animal products, and vultures are likely to constitute only a modest portion of the trade. This implies that the decline in access to vultures will not impact substantially on their livelihoods.

In total, some 1,251 traders, hunters and Traditional Healers could benefit annually from the trade in vultures, while there could be some 59,000 consumers per annum who benefit psychologically from vulture use.

Sustainability of the trade in vultures: An estimate of vulture population size and productivity was required to assess ecological sustainability of use levels. The data in the following table for each species are derived from KZN Wildlife monitoring records. 
Table 6: White-headed Vulture Trigonoceps occipitalis population and recruitment in KwaZulu-Natal (KZN) (2007)

\begin{tabular}{|l|l|l|}
\hline Protected Area & $\begin{array}{l}\text { Number of breeding pairs and } \\
\text { breeding success }\end{array}$ & Comment \\
\hline Phongola N.R. & 1 pair. & No chick. \\
\hline Mkhuze G.R. & 0 & $\begin{array}{l}\text { No breeding for last 3 years. } \\
\text { Occasionally 1 adult bird } \\
\text { seen. Population locally } \\
\text { extinct? }\end{array}$ \\
\hline Hluhluwe-iMfolozi & $\begin{array}{l}5 \text { breeding pairs. 3 chicks } \\
\text { known to be produced in 2006. }\end{array}$ & 1 nest unknown \\
\hline TOTAL FOR KZN & $\mathbf{6}$ breeding pairs remaining. & $\begin{array}{l}\text { No other nests known in } \\
\text { KZN. }\end{array}$ \\
\hline
\end{tabular}

Population size - 15 adult vultures in KZN (chicks, juveniles, immatures not included). Add 20\% for chicks, juveniles and immatures.

Table 7: White-backed Vulture Gyps africanus population and recruitment in KwaZuluNatal (2007)

\begin{tabular}{|l|l|l|}
\hline $\begin{array}{l}\text { Protected } \\
\text { Area }\end{array}$ & $\begin{array}{l}\text { Number of breeding pairs and } \\
\text { breeding success }\end{array}$ & Comment \\
\hline $\begin{array}{l}\text { Phongola } \\
\text { N.R. }\end{array}$ & $\begin{array}{l}34 \text { breeding pairs in } 2005 \text { reduced } \\
\text { to } 9 \text { in } 2006\end{array}$ & $\begin{array}{l}\text { Could be climatic factors - } \\
\text { unusually high winds, } \\
\text { unseasonal rains, inclement } \\
\text { weather - associated with } \\
\text { reduction in number of breeding } \\
\text { pairs. }\end{array}$ \\
\hline Mkhuze & $\begin{array}{l}15 \text { breeding pairs produced chicks } \\
\text { in } 2006\end{array}$ & $\begin{array}{l}35 \text { active nests (breeding pairs) } \\
\text { counted in reserve. }\end{array}$ \\
\hline $\begin{array}{l}\text { Hluhluwe- } \\
\text { iMfolozi } \\
\text { (HiP) }\end{array}$ & 275 breeding pairs & $\begin{array}{l}\text { Population regarded as "safe". } \\
\text { For how long? }\end{array}$ \\
\hline $\begin{array}{l}\text { TOAL FOR } \\
\text { KZN }\end{array}$ & $\mathbf{3 4 4}$ breeding pairs & \\
\hline
\end{tabular}

Population sizes - 88 (Phongola), Mkhuze - 91 Vultures, HiP - 715) TOTAL - 894 adult Vultures for KZN. Add 20\% to include immatures, juveniles and chicks). 
Table 8: Lappet-faced Vulture Torgos tracheliotos population and recruitment (2007)

\begin{tabular}{|l|l|l|}
\hline $\begin{array}{l}\text { Protected } \\
\text { Area }\end{array}$ & $\begin{array}{l}\text { Number of breeding pairs } \\
\text { and breeding success }\end{array}$ & Comment \\
\hline Ithala G.R. & 1 & Breeding success unknown \\
\hline Phongola N.R. & 1 (4 vultures maximum) & Breeding success unknown \\
\hline Mkhuze G.R. & 1 & Breeding success unknown \\
\hline $\begin{array}{l}\text { Hluhluwe- } \\
\text { iMfolozi }\end{array}$ & 6 & $\begin{array}{l}\text { 2 chicks known to have survived, } \\
\text { chick died, } 1 \text { unknown. } 50 \% \\
\text { productivity. }\end{array}$ \\
\hline $\begin{array}{l}\text { TOTAL FOR } \\
\text { KZN }\end{array}$ & $\mathbf{9}$ breeding pairs & \\
\hline
\end{tabular}

TOTAL - Approx 23 adult vultures in KZN. Add 20\% to include immatures, juveniles and chicks.

Table 9: Cape Vulture Gyps coprotheres population and recruitment (2007)

\begin{tabular}{|l|l|l|}
\hline Area & $\begin{array}{l}\text { Number of breeding pairs } \\
\text { and breeding success }\end{array}$ & Comment \\
\hline $\begin{array}{l}\text { KZN, Lesotho, E } \\
\text { Cape }\end{array}$ & 900 (Piper 2004) & $\begin{array}{l}\text { Assume approx. 70\% breeding } \\
\text { success based on previous } \\
\text { research (Mundy 1982) }\end{array}$ \\
\hline $\begin{array}{l}\text { Rest of South } \\
\text { Africa }\end{array}$ & 300 (Piper 2004) & $\begin{array}{l}\text { Assume approx. 70\% breeding } \\
\text { success }\end{array}$ \\
\hline & $\mathbf{1 2 0 0}$ & Data at least 2 years outdated. \\
\hline TOTAL & \\
\hline
\end{tabular}

TOTAL number of vultures in KZN, Eastern Cape, Lesotho - approximately 2160.

Total number for rest of SA - 720 (Totals include immatures, juveniles, chicks).

In all vulture species, approximately $70 \%$ of the population breeds. Vultures breed for four out of five years on average. Breeding age is 5 -6 years (Mundy 1982). 
Natural expected survival rates (all species):

- $\quad$ Fledglings - 50\% survive to 1 year old (first year vultures).

- $\quad$ First year vultures - 50\% of first year vultures survive.

- $\quad$ First year vultures to sexual maturity - 90\% survive.

Note - these figures are based on natural mortalities and do not account for man induced mortality. Longevity of vultures in the wild is not known.

\section{Average vulture breeding success} (theory):

- $\quad 0.5$ (fledglings) $\times \quad 0.5 \quad\left(1^{\text {st }}\right.$ year birds) $\times 0.9$ (Immature birds) = $0.225 \%$ of an adult. Therefore, two vultures divided by 0.225 years $=9$ years. Hence vultures need nine years to replace themselves.

- $\quad$ BUT the vultures need to reach sexual maturity, which is 6 years old.

- $\quad$ Six years (sexual maturity) + nine years (pair replacement) $=15$ years old by the time a bird can replace itself.
Reality in KwaZulu-Natal (working example from Phongola Nature Reserve):

- $\quad 0.3$ (fledglings) $\times 0.4 \quad\left(1^{\text {st }}\right.$ year birds) x 0.5 (Immature birds) = $0.06 \%$ of an adult. Therefore, 2 vultures divided by 0.06 years $=17$ years

- $\quad$ Then, 6 yrs (sexual maturity) +17 years (pair replacement) $=23$ years old by the time a bird replaces itself given the unnatural mortalities in KwaZulu Natal (not taking into account the current traditional use data).

As mentioned, longevity of wild vultures is unknown but is unlikely to be as long as approximately 30 years. If this longevity were realistic for wild vultures, the chances that the vultures would be breeding at this age are remote (Wakelin 2004).

The trade in vultures is not sustainable at the present harvest levels in the context of poor population recruitment. The implication is that for all those involved in the trade, the benefits currently enjoyed will no longer be available in the next 15 to 30 years from the time of this research. Table 10 illustrates the possible sustainability scenarios for the various species. 
Table 10. Possible scenarios for sustainability of the vulture trade.

\begin{tabular}{|l|l|l|l|l|}
\hline & & \multicolumn{3}{|c|}{ Scenario } \\
\hline \multirow{2}{*}{ Species } & & Market trend & Best case & $\begin{array}{l}\text { Worst } \\
\text { Case }\end{array}$ \\
\hline $\begin{array}{l}\text { White-backed and } \\
\text { White-headed } \\
\text { Vultures }\end{array}$ & $\begin{array}{l}\text { Annual rate of } \\
\text { population change }\end{array}$ & $-3.68 \%$ & $2.65 \%$ & $-9.23 \%$ \\
\cline { 2 - 5 } & $\begin{array}{l}\text { Years to population } \\
\text { loss }\end{array}$ & 27 & Vulnerable & 11 \\
\hline \multirow{3}{*}{ Cape Vulture } & $\begin{array}{l}\text { Annual rate of } \\
\text { population change }\end{array}$ & $-1.88 \%$ & $4.9 \%$ & $-8.03 \%$ \\
\cline { 2 - 5 } & $\begin{array}{l}\text { Years to population } \\
\text { loss }\end{array}$ & 53 & Stable & 12 \\
\hline
\end{tabular}

Table 10 is based on observed trade data (Approximately 160 vultures traded per year (Table 3)). Three possible scenarios based on market estimates from Table 3 are shown in Table 10 with the top figure being percentage population change and the bottom figure showing projected years to complete population loss. The "worst case" accounts for possible trade not observed during the survey and "best case" accounts for the survey over-estimating vulture trade figures. There were insufficient data to develop scenarios for Lappetfaced Vultures. White-backed Vultures in Zululand are clearly a major conservation concern. Under current conditions the population could become exhausted in 27 years, and should the survey have underestimated the intensity of use, then local extinction could be as little as 11 years away. This population cannot withstand the current environment and harvesting pressures being placed on it. The White-headed and Lappet-faced Vultures are populations that are likely to disappear in the near future unless there is a dramatic change in management effort.

The Cape Vultures appear to be stable. However, should the numbers of White-backed Vultures decline, a larger proportion of the current harvesting pressure (160 vultures per annum) could fall on the local Cape Vultures (while assuming current environmental pressures remain constant). In this instance, the Cape Vulture populations in Lesotho, KZN 
and Eastern Cape could be exhausted in 54 years.

The current levels of use need to be reduced and other negative pressures on the vulture populations in the region need to be reduced if these birds are to be conserved in eastern South Africa.

\section{Conclusions}

The trade in vultures is not sustainable unless there is a substantial change in the management of these populations and the pressures on them. White-backed Vultures in Zululand are a major conservation concern. Under current harvest pressure the population could become exhausted by 2034 (27 years from the time of this research), and should the survey have underestimated the intensity of use, then local extinction could be as close as 2018. This population cannot withstand the current environment and harvesting pressures being placed on it.

Populations of White-headed and Lappet-faced Vultures are likely to disappear in the near future unless there is a dramatic change in management effort.

The Cape Vulture population appears to be stable. However, should the numbers of White-backed vultures decline, a larger proportion of the current harvesting pressure (estimated 160 vultures per annum) could fall on the local Cape Vulture population (while assuming current environmental pressures remain constant). In this instance, the Cape Vulture populations in Lesotho, KZN and Eastern Cape could be exhausted in 54 years from the time of this research.

Vulture use forms part of the Traditional Healing industry, which is a strong and vital part of South Africa's culture, most particularly Zulu culture (Mander et al. 2007). The loss of vultures to this industry, which forms a unique part of the clairvoyant component of this Traditional Healing system, would be a major blow for this valuable cultural aspect of a majority of South Africans, as well as represent a significant loss of Traditional Knowledge.

The current levels of use need to be reduced and other negative pressures on the vulture populations in the region also need to be reduced if these vultures are to be conserved in eastern South Africa. An intervention strategy to address this issue should reduce the consumption and demand for vultures in the Traditional Medicine industry through awareness raising and promoting the use of alternatives, and improving the regulation of the trade 
through enhanced policy and policing. We recommend four broad key intervention areas:

1. Reduce consumption of and demand for vultures.

2. Change or create policy to improve broad scale regulation of the trade in vultures.

3. Improve policing and enforcement for better regulation of the trade.

4. Improve the understanding of the vulture trade to enable more focused interventions.

These intervention areas have been detailed in the full report on this research (Mander et al. 2007) and intervention plans have been developed and approved by KZN Wildlife for KwaZulu-Natal ( $\mathrm{M}^{\mathrm{c}}$ Kean and Rushworth 2008, 2013). However, implementation of these remains a challenge for capacity and resourcing reasons.

\section{References}

Berglund, A-I. 1976. Zulu thought patterns and symbolism. Almquist and Wiksell, Uppsala.

BirdLife International 2004. Threatened birds of the world 2004. BirdLife International, Cambridge.

Cunningham, A. B. \& Zondi, A.S. 1991. Use of animal parts for the commercial trade in traditional medicines. Working Paper No. 76. Institute of Natural Resources. Pietermaritzburg.

Mander, M. 1998. The marketing of indigenous medicinal plants in South Africa: A case study in KwaZulu-Natal. Food and Agriculture Organisation of the United Nations, Rome.

Mander M,, Diedrichs N., Ntuli L., Mavundla K., Williams V. and $\mathrm{M}^{\mathrm{C}}$ Kean S. 2007. Survey of the Trade in Vultures for the Traditional Health Industry in South Africa. Report for Ezemvelo KZN Wildlife, Pietermaritzburg. 54pp.

M'Kean, S. G. 1995. A Directory of Animal Species used for Traditional Medicine in KwaZulu-Natal. Ezemvelo KZN Wildlife Internal Report. 41pp. 
$M^{c}$ Kean, S. G. and Rushworth, I. A. 2008. Guidelines for Interventions to address the Threat of Traditional Use to Vultures. Ezemvelo KZN Wildlife Internal Report 10pp

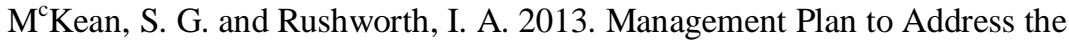
Threat of Traditional Use to Vultures. Ezemvelo KZN Wildlife Internal Report. 17pp

Mundy, P.J. 1982. The Comparative Biology of Southern African Vultures. Vulture Study Group. Johannesburg, South Africa

Ngwenya, M.P. 2001. Implications of the medicinal animal trade for Nature Conservation in KwaZulu-Natal. Ezemvelo KZN Wildlife Internal Report. 76pp.

Piper, S. E. 2004. Cape Griffon (Gyps coprotheres). In: Monadjem A, Anderson M D, Piper S E and Boshof A F (Eds). Proceedings of a workshop on vulture research and conservation in southern Africa. Kimberley, South Africa. April 2004.

Wakelin, J. 2004. Vulture Ringing in Phongolo and Mkhuze Game Reserves. Ezemvelo KZN Wildlife Internal Report. 9pp.

Whiting, M. J., Williams, V. L. and Hibbitts, T. J. 2011. Animals traded for traditional medicine at the Faraday market in South Africa: species diversity and conservation implications. Journal of Zoology 284:84-96.

Williams, V. L, Cunningham, A. B., Bruyns, R. K. and Kemp, A. C. 2013. Birds of a Feather: Quantitative Assessments of Diversity and Levels of Threat to Birds Used in African Traditional Medicine. In: Alves, R. and Rosa I. (Eds) Animals in Traditional Folk Medicine. pp 383 - 420. Springer, Berlin. 